\title{
The Effect of Learning Module Program on the Mothers' Ability to Adapt New Foods, Feeding Styles, and Self-Efficacy to Their Children with Avoidant Restrictive Food Intake Disorder (ARFID)
}

\section{yoyok bekti prasetyo ( $\nabla$ yoyok@umm.ac.id)}

Universitas Muhammadiyah Malang Fakultas Ilmu Kesehatan https://orcid.org/0000-0001-8801-7760

Nursalam Nursalam

Universitas Airlangga

Rahmat Hargono

Universitas Airlangga

Ahsan Ahsan

Universitas Brawijaya Fakultas Kedokteran

\section{Research article}

Keywords: Learning Module Program, Mothers' Ability to Adapt New Foods, Feeding Styles, and SelfEfficacy, Avoidant Restrictive Food Intake Disorder (ARFID)

Posted Date: December 14th, 2020

DOI: https://doi.org/10.21203/rs.3.rs-125364/v1

License: (9) This work is licensed under a Creative Commons Attribution 4.0 International License.

Read Full License 


\title{
The Effect of Learning Module Program on the Mothers' Ability to Adapt New Foods, Feeding Styles, and Self-Efficacy to Their Children with Avoidant Restrictive Food Intake Disorder (ARFID)
}

\author{
Yoyok Bekti Prasetyo ${ }^{1}$, Nursalam ${ }^{2}$, Rachmat Hargono ${ }^{3}$, Ahsan $^{4}$ \\ ${ }^{1}$ Department of Community Nursing, Faculty of Health Science, Universitas \\ Muhammadiyah Malang, ${ }^{2}$ Faculty of Nursing, Universitas Airlangga, ${ }^{3}$ Faculty of \\ Community Health, Universitas Airlangga, ${ }^{4}$ Study Program of Nursing Science, \\ Universitas Brawijaya
}

\begin{abstract}
Purpose: This study is to examine the effects of learning module program on the mothers' ability to adapt new foods, feeding styles, and self-efficacy to their children with Avoidant Restrictive Food Intake Disorder (ARFID). Methods: Quasiexperimental design without random sampling is used to evaluate the effectiveness of learning module program. There are 15 mothers take care of children with ARFID as experimental group given learning module program. The experimental group is conducted four meetings in four weeks. Each meeting has an effective 50 minutes. Fifteen mothers of control group are conducted home-visit by presenting the education of health to them. The control group intervention is performed two meetings. Meanwhile, the experimental group conducts pre-test and post-test. The data are analyzed by means of descriptive statistics, Chi-square test, Fisher's exact test, Mann-Whitney U test and SPSS/WIN 22.0. Results: The participants of experimental group have showed bigger surge of new foods adaptation $(t=-2.973, p$ $<0.003)$, feeding style $(\mathrm{t}=-4.646, \mathrm{p}<0.001)$, self-efficacy $(\mathrm{t}=-3.652, \mathrm{p}=0.001)$ than control group has. Conclusion: The findings indicated that the learning module program is deemed effective to improve mothers' ability to adapt new foods, feeding styles, and self-efficacy to their children with ARFID.
\end{abstract}

Key word: Learning Module Program, Mothers' Ability to Adapt New Foods, Feeding Styles, and Self-Efficacy, Avoidant Restrictive Food Intake Disorder (ARFID)

\section{Introduction}

The children with Avoidant Restrictive Food Intake Disorder (ARFID) are at high risk of experiencing growth and development disorder [1], [2]. One of the symptoms is difficult to adapt to the new foods [3]. They tend to less consume the variant of foods. The condition impairs the lack of nutritional intake [4]. Lack of variety in food and children's difficulties in adapting to new foods are caused by poor diet [5], [6]. Healthy dietary habit is greatly affected by family factor. In fact, a 
mother plays an important role in establishing healthy dietary habit since their childhood. If the mother has poor dietary habit, the children will have the same as well. [7]. Mainly, the mother taking care of children with ARFID frequently feels desperate of her children condition. She becomes less confident in solving the problem because she does not have good plan and tends to be apathetic [8], [9]. Finally the mother's inability to introduce new foods, to demonstrate healthy food dietary, and to show self-efficacy will severely causes children's nutritional status.

ARFID issue has been occurred from child to adult periods. The children with prevalence rate 3.2 percent of the overall population of 10 to 18 years old become 39 percent with 55 percent of comorbid status and 58 percent of anxiety [10]. The occurrence rate of children with eating disorder is reported 35 percent [11]. The parent reported that the children under pre-school age with eating new food problem are between 15 to 50 percent [12]. Meanwhile, feeding style problem is reported 19.3 percent, authoritarian 14 percent, and rejection 35.3 percent [13]. Feeding style permissive, authoritarian, and rejection in the family may impair poor dietary habit of children.

The education of mother's health is deemed important because it may solve the children's nutritional status. There is little research discussing education program delivered by the mother related to children's care with ARFID. The previous research stated that the education of nutrition based effective-community to improve dietary habit and children' growth [14]. Another research revealed that the education of nutrition based effective-community aims at optimizing children's nutrition in 1000 First-Day of Birth (HPK) [15] and educational program of sensitivity based effectivefamily improving mother's perspective to take care of her children [16]. Hence, this study focuses on the education program of nutrition to mother which is expected to be capable of practicing healthy dietary habit, adapting new food to her children, and increasing mother's self-efficacy to take care of children with ARFID. The purpose of this study to analyze the effect of health education program given by the mother 
towards the improvement of her ability to adapt new foods, healthy dietary habit, and her self-efficacy to the children.

\section{Methods}

The Design of the Study

This study applies a quasi-experimental, non-randomized, two-group designs with post-test to examine the effect of health education program given by the mother towards the improvement of her ability to adapt new foods, healthy dietary habit, and her self-efficacy to the children.

\section{Setting and Samples}

The population involved in this study is all mothers who take care of children with ARFID in region of Malang regency - Indonesia. The number of samples with Z in the normal curve for significance level $\alpha$ used in the direct test hypothesis 0.05 is 1.64. Then, the value of $\mathrm{Z}$ with the normal curve used in the direct test hypothesis 0.2 is 1.285. The standard deviation of the population from other research 0.65 is 15 mothers in the experimental group. Thus, the total samples of 30 mothers consist of 15 mothers in the experimental group and 15 mothers in the control group.

The inclusion criteria state the mother becoming a primary caregiver; mastering reading and writing abilities; and having physically and mentally healthy. The mother also experiences taking care of under five-children with ARFID, children with symptom, and children with eating disorder. Eating disorder affects children's sensory, such as food presentation, food smell and taste, children having no chronic disease and congenital anomaly. Furthermore, exclusion criteria state the mother indirectly taking care of the children (supported by a caregiver); the mother getting not ready; and the children with nutritional problem caused by congenital disorder.

\section{Ethical Considerations}

This study is conducted according to Declaration of Helsinki guidance. The ethical approval is issued by the committee of ethics of Community Health Faculty, Universitas Airlangga number 333-KEPK. All participants are asked to write down 
the informed consent and signature. Therefore, the privacy and confidentiality are highly secured.

Measurements

New foods adaptation

The questionnaire is used to measure the caregiver's behavior in improving children's social interaction skill and new foods familiarization. It consists of eight items ranging from $0-8$. The indicators of the questionnaire are (1) social activity stimulus; (2) communication support; (3) new foods availability; (4) feeding practice of new foods; (5) the children's engagement in food selection; (6) eating together; (7) letting the children to eat independently; and (8) avoiding new foods at same time. The Cronbach's alpha value is 0.82 . 
The learning module program on the mothers' ability to take care of children with ARFID

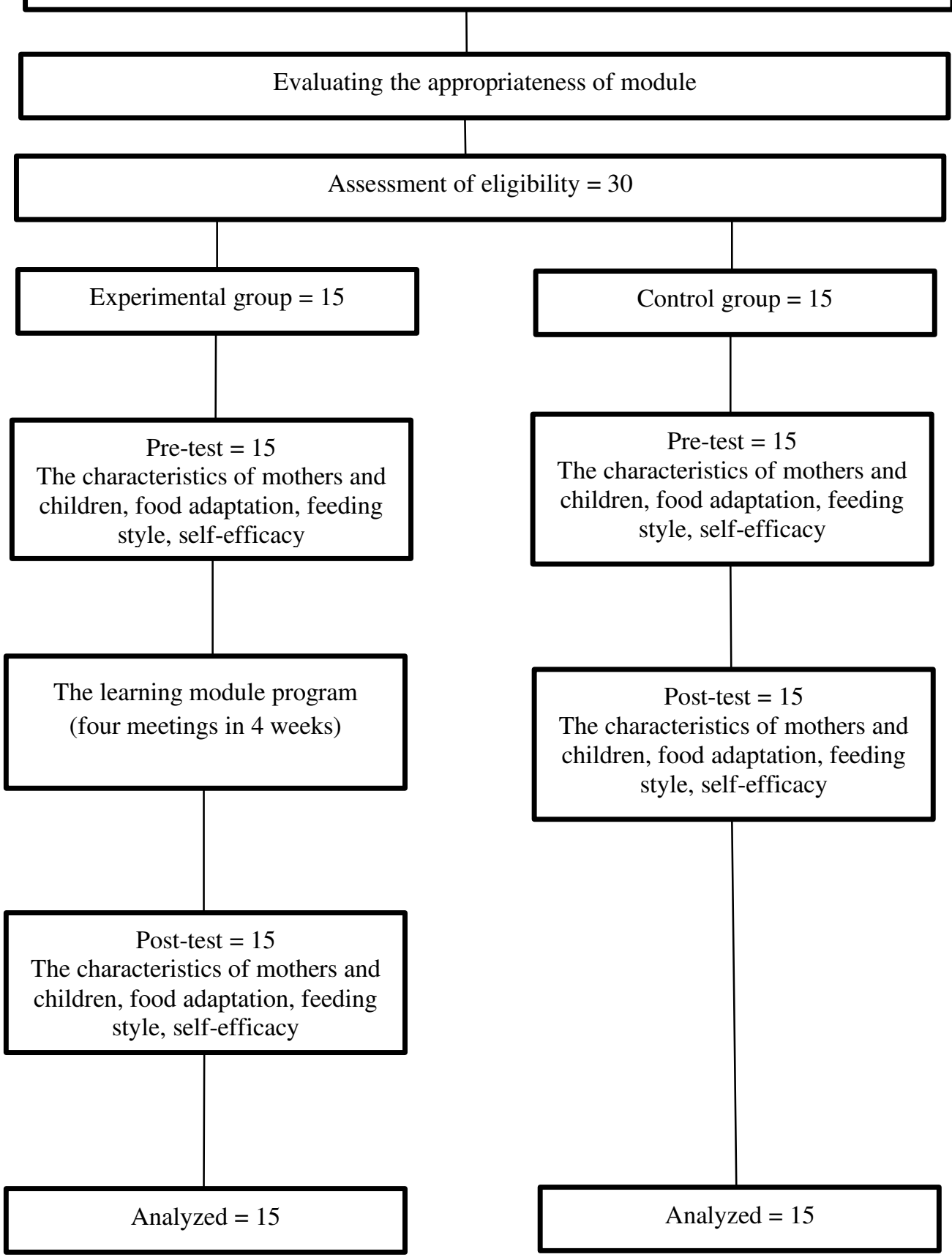




\section{Feeding style (practice)}

This questionnaire aims at evaluating the caregiver's feeding practice toward the children by considering responsive and communication aspects. It consists of seven items ranging from $0-7$. The indicators of the questionnaire are (1) children's motivation to share their own problem; (2) responsive; (3) developing children's understanding; (4) compliment; (5) good reason; (6) sharing the feelings; and (7) encouraging the children to talk about every action has its consequences. The Cronbach's alpha value is 0.84 .

\section{The learning module program}

The design of this study is adjusted by the condition faced by mother to take care of the children with ARFID. The module is created according to the process of the study at the first stage by identifying the determinant variable of mother's competence. Furthermore, focused group discussion (FGD) is conducted to examine the desire, point of view, need, trust, and experience of mothers in taking care of their children with ARFID. FGD is performed three times by involving the mothers, medical staffs, person in charge of nutritional program at health community center. The content validity of this module has been verified by a nursing professor (judging expert) in a nursing faculty. The specific structure and content of the learning module program are presented in the Table 1.

\section{Data Collection}

The data are collected in January - March 2019 by means of a structured questionnaire (mother and children characteristics, children's adaptation to the new foods, feeding style, and self-efficacy). All participants are given the information about the purposes and stages of this study and asked to fill informed consent form. The experimental group is distributed the learning module program and the technical intervention is performed four meetings in four weeks. Each meeting has an effective 50 minutes. The subject matters are about father's involvement (the first meeting), managing eating disorder (the second meeting), promotional behavior (the third meeting), and self-efficacy enhancement (the fourth meeting) delivered by means of 
power point visualization and projector display. The control group is performed by home-visit which the group is given health education and learning module in two meetings. The first meeting concerns about health education by presenting the materials with power point visualization and projector display. Then, the second meeting concerns about the same material as the first one without power point visualization and projector display. Furthermore, both groups conduct pre- and posttest.

Table 1 Description of Intervention

\begin{tabular}{|c|c|c|c|c|}
\hline $\begin{array}{l}\text { Session/ } \\
\text { meeting }\end{array}$ & $\begin{array}{c}\text { Educational } \\
\text { methods }\end{array}$ & Theme & Materials & $\begin{array}{c}\text { Duration } \\
\text { (min) }\end{array}$ \\
\hline 1 & $\begin{array}{l}\text { Face-to-face } \\
\text { education } \\
\text { session }\end{array}$ & $\begin{array}{l}\text { The father's } \\
\text { proximity } \\
\text { and parental } \\
\text { teamwork to } \\
\text { take care of } \\
\text { the children } \\
\text { with ARFID }\end{array}$ & $\begin{array}{l}\text { 1. Introduction } \\
\text { 2. Education: } \\
\text { a) Father's proximity } \\
\text { (Definition, roles, factors that } \\
\text { influence the father's } \\
\text { involvement, parenting effects of } \\
\text { father towards children' } \\
\text { development) } \\
\text { b) Parental teamwork } \\
\text { (Definition, the principles of } \\
\text { developing good interaction, } \\
\text { communication techniques) }\end{array}$ & $\begin{array}{l}5 \\
40\end{array}$ \\
\hline & & & 3. Question and answer (Q\&A) & 5 \\
\hline 2 & $\begin{array}{l}\text { Face-to-face } \\
\text { education } \\
\text { session }\end{array}$ & $\begin{array}{l}\text { The } \\
\text { improvement } \\
\text { of children's } \\
\text { adaptation } \\
\text { skill towards } \\
\text { eating new }\end{array}$ & $\begin{array}{l}\text { 1. Introduction } \\
\text { 2. Education; } \\
\text { a) Definition of adaptation } \\
\text { ability } \\
\text { b) How to improve children's } \\
\text { adaptation ability }\end{array}$ & $\begin{array}{l}5 \\
40\end{array}$ \\
\hline
\end{tabular}


foods

c) How to introduce new foods to the children

3. Question and answer (Q\&A)

5

1. Introduction 5

\begin{tabular}{llll}
\hline 3 & Face-to-face & Healthy & 1. Introduction \\
education & feeding & 2. Education: \\
session & styles for & a) Responsive feeding style \\
& children & b) Controling feeding style \\
& & c) Indulgen feeding style \\
& & d) Neglecful feeding style
\end{tabular}

3. Question and answer (Q\&A) 5

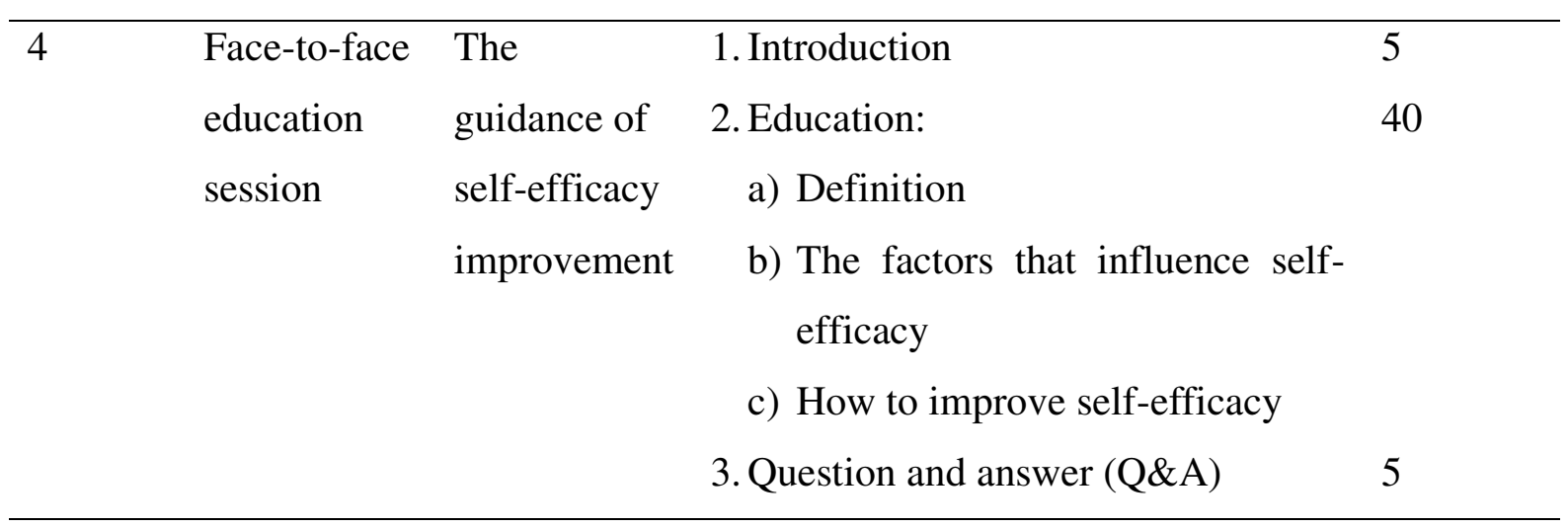

Data Analysis

The data are analyzed using SPSS 22 Software (IBM Incorporation, Chicago, IL, USA). The characteristics of mother and children in the experimental and control groups are analyzed by distributing the frequency, percentage, mean, and standard deviation. The analysis of the characteristics and variables in this study is performed homogeneity test with some related methods, such as Chi-square test, Fisher's exact test, t-test, and the Mann-Whitney U test. Moreover, Shapiro-Wilk test is applied to verify the variable's normality in a study. The non-normal distribution of variables is performed using the Mann Whitney $U$ test. Meanwhile, the reliability of the instruments (children's ability to adapt, feeding style, and self-efficacy) is analyzed using Cronbach's $\alpha$ parameter. The significance level is considered at $\mathrm{p}<0.5$.

\section{Results}




\section{Homogeneity}

In general, there is no difference between characteristics and variables of the study in the two groups. However, there is a difference between education characteristics and income per month (Table 2 and 3 ).

Table 2 Homogeneity test of the characteristics between the experimental and control groups $(\mathrm{N}=30)$

\begin{tabular}{|c|c|c|c|c|c|c|}
\hline \multirow{2}{*}{$\begin{array}{l}\text { Characteristi } \\
\text { cs }\end{array}$} & \multirow[t]{2}{*}{ Categories } & Total $(n=30)$ & Exp. $(n=15)$ & Con. $(n=15)$ & $X^{2}$ & $\mathrm{p}$ \\
\hline & & $\begin{array}{r}\mathrm{N}(\%) \text { or } \\
\mathrm{M} \pm \mathrm{SD}\end{array}$ & $\begin{array}{r}\mathrm{N}(\%) \text { or } \\
\mathrm{M} \pm \mathrm{SD}\end{array}$ & $\begin{array}{r}\mathrm{N}(\%) \text { or } \\
\mathrm{M} \pm \mathrm{SD}\end{array}$ & or $\mathrm{t}$ & \\
\hline \multirow[t]{2}{*}{ Age } & Mothers & $31.23 \pm 5.72$ & $31.60 \pm 5.53$ & $30.87 \pm 6.07$ & 0.73 & 0.563 \\
\hline & Children & $2.48 \pm 1.27$ & $2.31 \pm 1.03$ & $2.64 \pm 1.49$ & $\begin{array}{r}2 \\
0.48 \\
9\end{array}$ & 0.105 \\
\hline \multirow{4}{*}{$\begin{array}{l}\text { Education } \\
\text { Levels }\end{array}$} & \multirow{2}{*}{$\begin{array}{l}\text { Elementary } \\
\text { School }\end{array}$} & $3(10)$ & $0(0)$ & $3(20)$ & 0.04 & 0.000 \\
\hline & & & & & 0 & \\
\hline & $\begin{array}{l}\text { Junior } \\
\text { School }\end{array}$ & $5(16.7)$ & $1(6.7)$ & $4(26.7)$ & & \\
\hline & $\begin{array}{l}\text { Senior High } \\
\text { School }\end{array}$ & $22(73.3)$ & $14(93.3)$ & $8(53.3)$ & & \\
\hline \multirow[t]{2}{*}{ Status $^{a}$} & Employment & $6(20)$ & $2(13.3)$ & $4(26.7)$ & $\begin{array}{r}0.65 \\
1\end{array}$ & 0.075 \\
\hline & Unemployment & $24(80)$ & $13(86.7)$ & $11(73.3)$ & & \\
\hline \multirow[t]{3}{*}{$\begin{array}{l}\text { Number of } \\
\text { Children }\end{array}$} & 1 & $17(56.7)$ & $8(53.3)$ & $9(60)$ & $\begin{array}{r}1.00 \\
0\end{array}$ & 0.527 \\
\hline & 2 & $8(26.7)$ & $5(33.3)$ & $3(20)$ & & \\
\hline & 3 & $5(16.7)$ & $2(13.3)$ & $3(20)$ & & \\
\hline \multirow[t]{3}{*}{$\begin{array}{l}\text { Income } \\
\text { month }\end{array}$} & $<1$ million & $5(16.7)$ & $3(20)$ & $2(13.3)$ & $\begin{array}{r}0.05 \\
6\end{array}$ & 0.010 \\
\hline & $1-2$ millions & $18(60)$ & $6(40)$ & $12(80)$ & & \\
\hline & $>2$ millions & $7(23.3)$ & $6(40)$ & $1(6.7)$ & & \\
\hline \multirow{2}{*}{$\begin{array}{l}\text { Children's } \\
\text { gender }\end{array}$} & males & $17(56.7)$ & $9(60)$ & $8(53.3)$ & 0.71 & 0.526 \\
\hline & females & $13(43.3)$ & $6(40)$ & 7 (46.7) & & \\
\hline
\end{tabular}

Note: Exp. $=$ Experimental Group; Con. $=$ Control Group; $\mathrm{M}=$ Mean; SD = Standard Deviation; ${ }^{\text {a}}$ Fisher's exact test.

Table 3 Homogeneity test of the study variables $(\mathrm{N}=30)$

\begin{tabular}{llllll}
\hline Variables & Total $(n=30)$ & Exp. $(n=15)$ & Con. $(n=15)$ & t or $Z$ & $p$
\end{tabular}




\begin{tabular}{lrrrrr}
\cline { 2 - 4 } & $\mathrm{M} \pm \mathrm{SD}$ & $\mathrm{M} \pm \mathrm{SD}$ & $\mathrm{M} \pm \mathrm{SD}$ & & \\
\hline Children's & $5.80 \pm 1.12$ & $6.80 \pm 0.49$ & $4.8 \pm 0.49$ & 0.000 & 1.000 \\
adaptation & & & & & \\
Feeding style & $5.61 \pm 0.79$ & $6.23 \pm 0.49$ & $5.0 \pm 0.50$ & 0.000 & 0.854 \\
Self-efficacy & $3.30 \pm 0.63$ & $3.80 \pm 0.32$ & $2.80 \pm 0.45$ & 0.000 & 0.092 \\
\hline
\end{tabular}

\section{The Adaptation to New Food}

The mother as a caregiver must comprehend the situation of how to adapt new foods to the children using the learning module program - the mothers' ability to take care of the children with ARFID. The experimental group experiences more significant progress $(\mathrm{t}=-2.973, \mathrm{p}<0.003)$ than the control group (Table 4$)$.

\begin{tabular}{llccccc}
\hline Variables & Group & Pre-test & Post-test & Difference & t or Z & $\mathrm{p}^{\mathrm{a}}$ \\
\cline { 3 - 5 } & & $\mathrm{M} \pm \mathrm{SD}$ & $\mathrm{M} \pm \mathrm{SD}$ & $\mathrm{M} \pm \mathrm{SD}$ & & \\
\hline New foods & Exp. & $6.13 \pm 0.743$ & $7.47 \pm 0.516$ & $1.34 \pm 0,227$ & -4.735 & $<0.001$ \\
adaptation & Con. & $4.57 \pm 0.617$ & $4.93 \pm 0.594$ & $0.36 \pm 0.023$ & & \\
\hline Feeding style & Exp. & $6.00 \pm 0.655$ & $6.47 \pm 0.516$ & $0.47 \pm 0.139$ & -4.646 & $<0.001$ \\
& Con. & $4.73 \pm 0.458$ & $5.27 \pm 0.799$ & $0.54 \pm 0.341$ & & \\
\hline Self-efficacy & Exp. & $3.73 \pm 0.458$ & $3.87 \pm 0.352$ & $0.14 \pm 0.106$ & -3.652 & 0.001 \\
& Con. & $2.40 \pm 0.632$ & $3.20 \pm 0.561$ & $0.80 \pm 0.071$ & & \\
\hline
\end{tabular}

Note: ${ }^{a}$ Mann Whitney Test

Feeding Styles

The understanding of the mother in the experimental group to manage new foods to the children with ARFID using the learning module program is more significant $(\mathrm{t}=-4.646, \mathrm{p}<0.001)$ than the control group $($ Table 4$)$.

Self-efficacy

The mother's self-efficacy to take care of children with ARFID in the experimental group using the learning module program is more significant $(\mathrm{t}=$ $3.652, \mathrm{p}=0.001)$ than the control group (Table 4).

\section{Discussion}


This study aims at developing the learning program for mothers to take care of the children with ARFID. The learning module program explains about how to adapt to new foods, to implement healthy dietary habit, and to improve the mother's self-efficacy.

\section{New Foods Adaptation}

This study discusses about the mother as a caregiver to take care of the children with ARFID and ta assist them with new foods consumption. These efforts are indicated by encouraging the children to join social activities, presenting new foods, demonstrating of eating new foods in front of them, involving the children to select the food independently, eating together with family, letting them eating any kind of foods, and avoiding to offer new foods in the same time. Parental readiness in giving new foods based on their age is deemed important to prevent neophobia [17]. Presenting examples of new foods, involving children to choose the foods and letting new foods in children are very important for children to adapt to new foods. The children recognize the foods from their appearance, texture, and smell [18]. The frequency of children's exposure to consume new foods is also related to the acceptance of children to new foods [19]. Two important things for parents to do in adapting their children to new foods are social and cognitive environmental factors. Social environmental factors include parental support, pressure during meals, and parental strategies. The cognitive factors affected children's appetites are disgust, texture, appearance, and smell of food [20]. The parent must concern on food presentation because an interesting food display will stimulate children's sensory and motivation to try [21]. Parental awareness to adapt their children plays an important factor to increase children's control to respect themselves and others. This is in accordance with the opinion that increasing children's adaptability means increasing children's social skills. Increasing adaptability is a social development for children to play around which allows them to develop their empathy and interact more frequently. It can increase children's awareness to share and be more able to respect themselves and others [22], [23]. 


\section{Feeding Styles}

In this study, the ability of caregivers to take care of children with ARFID in adopting a better diet has also increased. This is indicated by behaviors such as encouraging children to convey their problems, being responsive to children's feelings and needs, giving compliment, giving reasons to children why rules must be obeyed. Indeed, the parents will greatly determine children' eating behavior. Children's eating practice is highly determined by the healthy style or diet of the parents [24], [25]. The pattern of proper feeding from infancy will lead to good eating behavior at a later age [12], [26]. Feeding style describes the interaction between parents and children related to the behavior and role of parents in controlling children to eat such as how much the portion, when the child eats, limiting food, and using food as a gift. Feeding style can be formed from two dimensions, namely needs and responsiveness. The dimension of the demand for food needs is related to the motivation of parents towards children to eat, while the responsiveness dimension is more about how parents pay attention to their children's interest in food, making children eat because of sensory aspects of food, such as appearance, taste, and smell of food [27].

\section{Self-efficacy}

The ability of caregivers to take care of the children with ARFID in increasing self-efficacy has also changed for the better. This is shown by the mother's behavior in identifying her own weaknesses and strengths, increasing her ability to set goals, doing affirmations, and relax. Self-confidence in the ability of a mother to overcome ARFID problems in children is an important asset in solving ARFID cases in family. Strong self-efficacy will encourage mothers to take care of their children properly. Moreover, it will maintain mother's motivation, realistic goals, and emotions. Selfefficacy is the belief to succeed in carrying out behaviors that lead to the desired results [28], [29]. Self-efficacy defines the personal confidence or ability to take action. Furthermore, self-efficacy is a personal belief in his ability to carry out a special task or part of the various components of the task [30]. High self-efficacy will 
achieve a better performance because the individual has strong motivation, clear goals, stable emotions and the ability to perform a successful activity or behavior [31].

\section{Conclusion}

Based on the results of the study, it can be concluded that the learning module program on the mothers' ability to take care of children with ARFID can improve the ability to adapt new foods to children, adopt better eating patterns, and increase selfefficacy. The learning module program on the ability to take care of children with ARFID can be recommended as an intervention in the field of community nursing that focuses on improving nutrition on the children with ARFID.

\section{Conflicts of interest}

The authors declare that they have no conflict of interest.

\section{References}

[1] Z. Alberts, M. Fewtrell, D. E. Nicholls, L. Biassoni, M. Easty, and L. D. Hudson, "Bone mineral density in Anorexia Nervosa versus Avoidant Restrictive Food Intake Disorder," Bone, vol. 134, no. November 2019, p. 115307, 2020, doi: 10.1016/j.bone.2020.115307.

[2] R. Ma, K. P. Capobianco, N. C. T. Buchanan, Z. Hu, and J. M. Oakman, "Etiologic and treatment conceptualizations of disordered eating symptoms among mainland Chinese therapists," Int. J. Eat. Disord., vol. 53, no. 3, pp. 391-403, 2020, doi: 10.1002/eat.23204.

[3] W. G. Sharp, V. M. Volkert, L. Scahill, C. E. Mccracken, and B. Mcelhanon, "A Systematic Review and Meta-Analysis of Intensive Multidisciplinary Intervention for Pediatric Feeding Disorders: How Standard Is the Standard of Care?," J. Pediatr., vol. 181, pp. 116-124.e4, 2016, doi: 10.1016/j.jpeds.2016.10.002.

[4] F. Feillet et al., "Nutritional risks of ARFID (avoidant restrictive food intake disorders) and related behavior," Arch. Pédiatrie, vol. 26, no. 7, pp. 437-441, 2019, doi: https://doi.org/10.1016/j.arcped.2019.08.005.

[5] E. Jansen, H. Harris, L. Daniels, K. Thorpe, and T. Rossi, "Acceptability and accessibility of child nutrition interventions: Fathers' perspectives from survey and interview studies," Int. J. Behav. Nutr. Phys. Act., vol. 15, no. 1, pp. 1-12, 2018, doi: 10.1186/s12966-018-0702-4.

[6] T. A. Bekelman, L. L. Bellows, and S. L. Johnson, "Are Family Routines Modifiable Determinants of Preschool Children's Eating, Dietary Intake, and Growth? A Review of Intervention Studies," Curr. Nutr. Rep., vol. 6, no. 2, pp. 
171-189, 2017, doi: 10.1007/s13668-017-0207-9.

[7] Y. B. Prasetyo et al., "Factors influencing promotive behaviours in mothers of Indonesian children with avoidant restrictive food intake disorder," J. Taibah Univ. Med. Sci., vol. 14, no. 5, pp. 454-459, 2019, doi: 10.1016/j.jtumed.2019.07.003.

[8] E. Ulfiana, P. D. Rachmawati, and D. K. Fadhilah, "Contributing factors of the mother's behavior in fulfilling nutritional needs for under-five children with overweight and obesity," Indian J. Public Heal. Res. Dev., vol. 10, no. 8, pp. 2713-2718, 2019, doi: 10.5958/0976-5506.2019.02280.0.

[9] L. R. Bader, H. N. Fouts, and J. Jaekel, "Infant Behavior and Development Mothers ' feelings about infants 'negative emotions and mother- infant interactions among the Gamo of Southern Ethiopia," Infant Behav. Dev., vol. 54, no. December 2018, pp. 22-36, 2019, doi: 10.1016/j.infbeh.2018.09.005.

[10] H. Krom et al., "Health related quality of life of infants and children with avoidant restrictive food intake disorder," Int. J. Eat. Disord., vol. 52, no. 4, pp. 410-418, 2019, doi: 10.1002/eat.23037.

[11] T. M. Dovey, V. Kumari, and J. Blissett, "Eating behaviour , behavioural problems and sensory pro fi les of children with avoidant / restrictive food intake disorder ( ARFID ), autistic spectrum disorders or picky eating: Same or different?," Eur. Psychiatry, vol. 61, pp. 56-62, 2019, doi: 10.1016/j.eurpsy.2019.06.008.

[12] K. Walton, L. Kuczynski, E. Haycraft, A. Breen, and J. Haines, "Time to rethink picky eating ?: a relational approach to understanding picky eating," Int. J. Behav. Nutr., vol. 14, no. 62, pp. 1-8, 2017, doi: 10.1186/s12966-017-05200 .

[13] K. E. Van Der Geest, S. Y. M. Mérelle, G. Rodenburg, D. Van De Mheen, and C. M. Renders, "Cross-sectional associations between maternal parenting styles , physical activity and screen sedentary time in children," BMC Public Health, vol. 17, no. 753, pp. 1-10, 2017, doi: 10.1186/s12889-017-4784-8.

[14] N. Sharma, M. Gupta, A. K. Aggarwal, and M. Gorle, "Effectiveness of a culturally appropriate nutrition educational intervention delivered through health services to improve growth and complementary feeding of infants: A quasi-experimental study from Chandigarh ," PLoS One, vol. 15, no. 3, pp. 122, 2020, doi: 10.1371/journal.pone.0229755.

[15] R. Naim, N. Juniarti, and A. Yamin, "Pengaruh Edukasi Berbasis Keluarga terhadap Intensi Ibu Hamil untuk Optimalisasi Nutrisi pada 1000 Hari Pertama Kehidupan," J. Keperawatan Padjadjaran, vol. 5, no. 2, pp. 185-196, 2017, doi: $10.24198 / \mathrm{jkp} . v 5 \mathrm{i} 2.475$.

[16] D. Indriyani and S. W. Asih, "Family-Based Maternal Sensitivity Model as a Strategy to Optimize Family Perception on the Role of Parents and the Growth of Infants," J. Ners, vol. 13, no. 1, p. 17, 2018, doi: 10.20473/jn.v13i1.5690.

[17] A. I. Gomes, L. Barros, A. I. Pereira, M. So, and M. Mendonça, "Assessing children' $s$ willingness to try new foods : Validation of a Portuguese version of the child 's food neophobia scale for parents of young children," Food Qual. Prefer., vol. 63, no. January 2017, pp. 151-158, 2018, doi: 
10.1016/j.foodqual.2017.09.002.

[18] K. J. Moding, L. L. Bellows, K. J. Grimm, and S. L. Johnson, "Physiology \& Behavior A longitudinal examination of the role of sensory exploratory behaviors in young children' s acceptance of new foods," Physiol. Behav., vol. 218, no. July 2019, p. 112821, 2020, doi: 10.1016/j.physbeh.2020.112821.

[19] C. Houston-price, L. H. Owen, O. B. Kennedy, and C. Hill, "Parents ' experiences of introducing toddlers to fruits and vegetables through repeated exposure, with and without prior visual familiarization to foods: Evidence from daily diaries 设," Food Qual. Prefer., vol. 71, no. May 2018, pp. 291300, 2019, doi: 10.1016/j.foodqual.2018.08.003.

[20] H. Alawi et al., "Food neophobia and pickiness among children and associations with socioenvironmental and cognitive factors," Appetite, vol. 142, no. July, p. 104373, 2019, doi: 10.1016/j.appet.2019.104373.

[21] E. Maiz, I. Urkia, A. Bereciartu, E. Urdaneta, and X. Allirot, "Introducing novel fruits and vegetables : Effects of involving children in artistic plating of food," Food Qual. Prefer., vol. 77, no. January, pp. 172-183, 2019, doi: 10.1016/j.foodqual.2019.05.006.

[22] R. Hassan, A. S. Mills, K. L. Day, R. J. Van Lieshout, and L. A. Schmidt, "Relations among Temperament, Familial Socioeconomic Status, and Inhibitory Control in Typically Developing Four-Year-Old Children," J. Child Fam. Stud., pp. 950-958, 2019, doi: 10.1007/s10826-019-01329-4.

[23] E. S. Astuti, N. Nursalam, S. R. Devy, and R. Etika, "Mother's independence model within caring for low birth weight babies at home after hospital care based on mother factors, family support, and social support," Indian J. Public Heal. Res. Dev., vol. 10, no. 10, pp. 1685-1690, 2019, doi: 10.5958/09765506.2019.03085.7.

[24] P. A. Graziano et al., "Feasibility of Intensive Parent-Child Interaction Therapy (I-PCIT): Results from an Open Trial," J. Psychopathol. Behav. Assess., vol. 37, no. 1, pp. 38-49, 2015, doi: 10.1007/s10862-014-9435-0.

[25] F. S. Tetra Dewi, H. Stenlund, V. U. Marlinawati, A. Öhman, and L. Weinehall, "A community intervention for behaviour modification: an experience to control cardiovascular diseases in Yogyakarta, Indonesia.," BMC Public Health, vol. 13, p. 1043, 2013, doi: 10.1186/1471-2458-13-1043.

[26] D. R. Sjarif, K. Yuliarti, L. K. Wahyuni, T. Wiguna, T. Prawitasari, and Y. Devaera, "Effectiveness of a comprehensive integrated module using interactive lectures and workshops in understanding and knowledge retention about infant feeding practice in fifth year medical students: a quasiexperimental study," BMC Med. Educ., pp. 1-9, 2016, doi: 10.1186/s12909016-0705-2.

[27] K. Van Der Horst and E. F. C. Sleddens, "Parenting styles, feeding styles and food- related parenting practices in relation to toddlers ' eating styles: A cluster-analytic approach," PLoS One, vol. 12, no. 5, pp. 1-17, 2017, doi: 10.1371/journal.pone.0178149.

[28] P. Colditz et al., "Prem Baby Triple P: a randomised controlled trial of 
enhanced parenting capacity to improve developmental outcomes in preterm infants.," BMC Pediatr., vol. 15, no. 1, p. 15, 2015, doi: 10.1186/s12887-0150331-X.

[29] L. Dawson, B. Mullan, and K. Sainsbury, "Using the theory of planned behaviour to measure motivation for recovery in anorexia nervosa," Appetite, vol. 84, pp. 309-315, 2014, doi: 10.1016/j.appet.2014.10.028.

[30] V. Shofiah and Raudatussalamah, "Self- efficacy dan self-regulation sebagai unsur penting dalam pendidikan karakter," 2010.

[31] V. Trilolita and P. Ardi, "Pengaruh self efficacy terhadap employee enggement dan kinerja karyawan ( Studi pada Karyawan PT Telekomunikasi Indonesia Regional V Surabaya )," J. Adm. Bisnis, vol. 52, no. 1, pp. 163-172, 2017. 
The learning module program on the mothers' ability to take care of children with ARFID

Evaluating the appropriateness of module

Assessment of eligibility $=30$

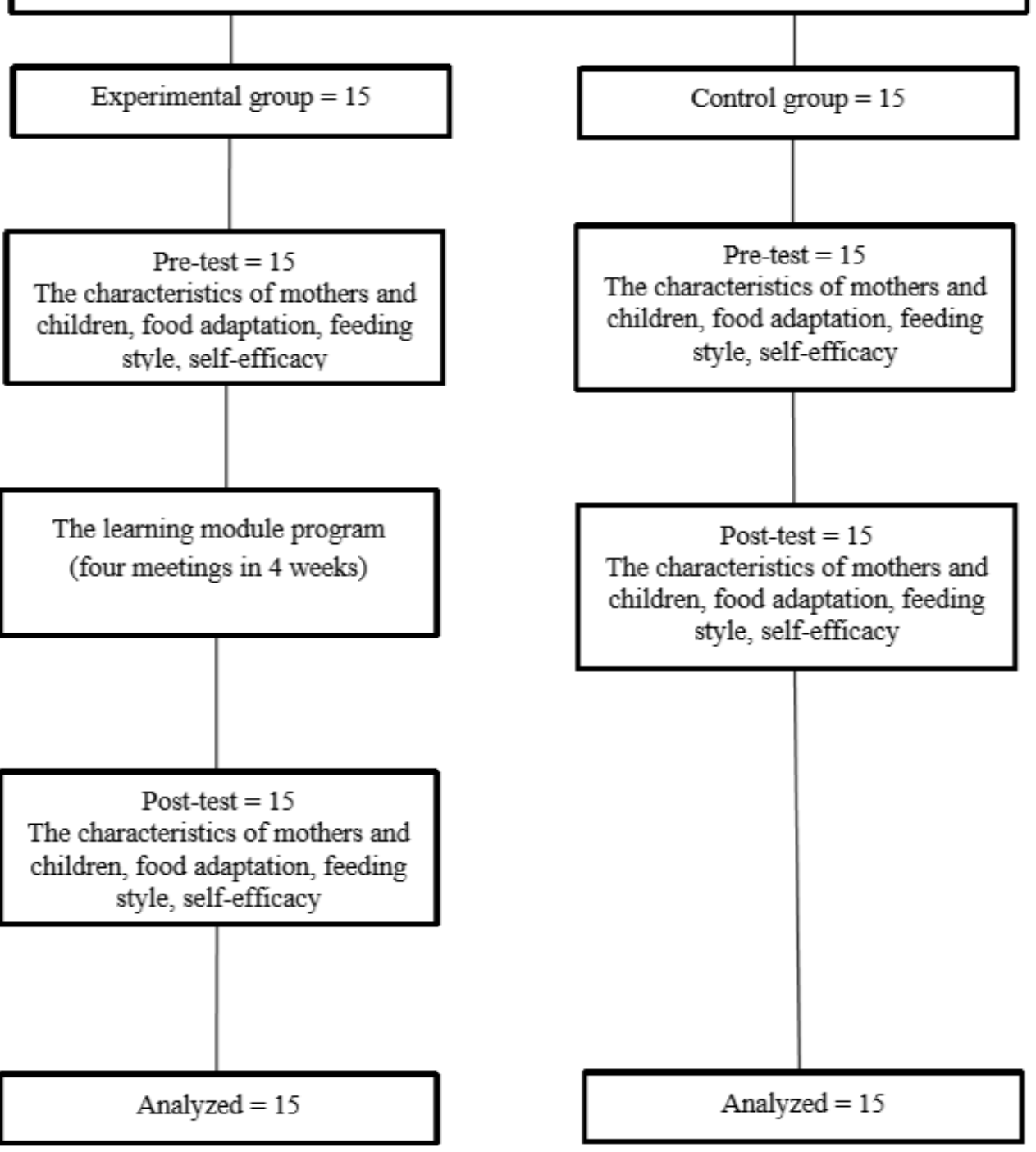

\section{Figure 1}

Flowchart 